\title{
Afetlere Müdahale Eden Yardım Personelini Güçlendirme
}

\author{
Vedat Işıkhan ${ }^{1, *}$ \\ ${ }^{1}$ Hacettepe Üniversitesi, Iktisadi ve İdari Bilimler Fakültesi, Sosyal Hizmet Bölümü, 06800, Ankara.
}

\section{Özet}

Tüm dünyada afetlerin yaratmış olduğu olumsuz sonuçlar gün geçtikçe artıș göstermektedir. Afetler her yll küresel düzeyde milyonlarca insanı etkilerken ne yazık ki toplumda yaşanan eșitsizliği ve adaletsizliği de hızlandırmaktadır. Afetlerin siklı̆̆l ve insanlar üzerine etkisi, iklimsel değişmeler ve artan nüfus yoğunluğu sebebiyle artmış durumdadır. Günümüzde deprem, sel, kuraklık, yangınlar, volkanik ve nükleer patlamalar, terörist saldırılar adeta sıradan olaylara dönüșmüștür. Bu doğrultuda doğal veya insan kaynaklı afetlerin kazazede ve toplumlar üzerindeki etkileriyle ilgili literatür oldukça fazladır. Afet ruh sağlı̆̆ literatüründen elde ettiğimiz bulgular, ilk müdahaleyi yapan kurtarma ekibinin, afetlere müdahale ettikten sonra travmatik deneyimlere doğrudan ve sürekli maruz kaldıklarından olumsuz psikolojik sonuçlar için bir risk taşıdıklarını bildirmektedir. Afetlere anında müdahale eden ve mağdurlara yardımcı olan yardım personeli (arama kurtarma ekibi, itfaiyeci, destek grupları vb.), afet sonrasında çeşitli sorunlarla karşı karşılya kalabilmektedir. Ancak literatürde yaşanan afetlerin bu yardım personeli üzerindeki etkileri ile ilgili çalışmaların sınırlı olduğu belirlenmiştir. Bu çalı̧̧mada, afet literatürü, afet ruh sağlı̆̆ ilişkisi, afetlerin genel sonuçlarl, afetlerin yardım personeli üzerindeki psiko-sosyal, fiziksel ve davranışsal etkileri, bunların semptomları ve bu personele nasıl yardım edilebileceği ve güçlendirileceği tartışılmaktadir.

\section{$\underline{\text { Anahtar Sözcükler }}$}

Afet, Travma Sonrası Stres Bozukluğu, Güçlendirme, Sosyal Hizmet, Yardım Personeli, İnsani Yardım Personeli

\section{Empowering Aid Personnel That Respond to Disasters}

\begin{abstract}
All over the world, the negative consequences of disasters are increasing day by day. While disasters affect millions of people globally each year, unfortunately they also accelerate the inequality and injustice in the society. The frequency of disasters and their impact on people has increased due to climatic changes and increasing population density. Today, earthquakes, floods, drought, fires, volcanic and nuclear explosions, terrorist attacks have turned into ordinary events. Accordingly, the literature on the effects of natural or manmade disasters on victims and communities is abundant. Our findings from the disaster mental health literature indicate that the rescue team that performs the first responders has a risk for negative psychological consequences as they are directly and continuously exposed to traumatic experiences after intervening in disasters. Aid personnel (search and rescue team, firefighters, support groups, etc.) who immediately respond to disasters and assist victims may face various problems after disaster. However, it has been determined that the studies in the literature on the effects of disasters and disasters on these aid personnel are limited. The following study discusses the disaster literature, the relationship of disaster mental health, the general consequences of disasters, the psycho-social, physical and behavioral effects of disasters and disasters on aid personnel, their symptoms, and how to help and strengthen these personnel.
\end{abstract}

$\underline{\text { Keywords }}$

Disaster, Post Traumatic Stress Disorder, Empowerment, Social Work, Aid Staff, Human Services Staff

\section{Giriş}

Afetler her yıl küresel düzeyde milyonlarca insanı etkiler. Dünya çapında ortalama her gün en az bir afet yaşanır. Afetlerin sıklığı ve insanlar üzerine etkisi, iklimsel değişmeler ve artan nüfus yoğunluğu sebebiyle artmıș durumdadır. 2005 yılında 162 milyon insan küresel düzeyde yaşanan afetlerden etkilenmiştir. 2010 yılında ise bu rakam 330 milyondan daha fazla olmuştur. Dünyanın bazı bölgeleri diğer bölgelere göre daha çok etkilenmiştir. Örneğin; 2010'da dünya genelinde Çin'de yaşayanların neredeyse dörtte üçü afetlerden etkilenmiştir. Amerika Birleşik Devletleri’ndeki geniş çaplı bir toplumsal araştırma, yaşamlarında bir kez afet yaşayan yetişkinlerin oranının \%13-19 arası olduğunu göstermiştir (Burkle 1996; Goldmann ve Galea 2014; McFarlane ve Williams 2012; Aslan 2018).

Afetler; genellikle beklenilmeyen ve ölüm, travma, yıkım gibi büyük çaptaki olaylardır. Afetlerin geçerli bir tanımı olmamasına rağmen araştırmacılar genellikle afetlerin geniş çaplı travmatik olaylar olarak üç temel özellik taşıdığına katılmaktadır. İlk olarak, afetler kaybolan yaşamların gerçek boyutlarına bakılmaksızın insanların büyük bir bölümünü etkiler veya ölümle tehdit eder. 
İkinci olarak, sosyal süreçleri etkiler, hizmetlerin, sosyal ilişkilerin ve kaynakların toplumsal kaybına sebep olur. Üçüncü olarak, ikincil sonuçlar içerir. Yarattığı ruhsal ve fiziksel sağlık sonuçlarıyla insanları uzun süre etkiler.

Travmatik olayların insanları nasıl etkilediği uzun yıllar boyunca çalışma konusu olmuştur. Çok sayıda araştırma, trafik kazaları ve cinsel saldırı gibi bireysel olaylardan doğal afetler, uçak kazaları ve toplumsal şiddet gibi toplum çapındaki olaylara ve savaş gibi küresel olaylara kadar değişen travmatik olayları incelemiştir. Ancak, afetlere anında müdahale eden yardım personelinin afetlerden psikolojik, sosyal ve ekonomik yönden nasıl etkilendiğini gösteren araştırmaların sayısı sınırlıdır. Aslında gerek bireysel gerekse toplum olarak bir afette ne yapılması gerektiği hakkında profesyonel bir bilgiye sahip değiliz (Burkle 1996; Goldmann ve Galea 2014; McFarlane ve Williams 2012).

Bir afet olayına müdahale eden birçok personel bulunmaktadır. Profesyonele yardım; 'bireyin fiziksel, psikolojik, entelektüel, duygusal veya ruhsal iyiliğinin ilaç, bakım, psikoterapi, psikolojik rehberlik, sosyal hizmet, eğitim, yardım ile ele alınarak büyümesini ve gelişmesini sağlayan bir uzmanlık alanıdır. Birçok çalışmada bu personeli tanımlamak için; yardım eden, afet personeli, acil yardım personeli, yardım profesyoneli, yardım personeli, sağlık personeli gibi farklı isimlerin kullanıldığı görülmüştür (Goldmann ve Galea 2014). Bu çalışmada yardım personeli; afet durumunda mağdurlara yardım için seferber olan; itfaiyecileri, ilk yardım personelini, doktorları, hemşireleri, psikologları, insani yardım personeli ve sosyal hizmet uzmanlarını (SHU) ifade etmek amacıyla kullanılmıştır.

Afet ruh sağlığı literatüründen elde edilen bulgular, ilk müdahaleyi yapan kurtarma ekibinin, afetlere müdahale ettikten sonra travmatik deneyimlere doğrudan ve sürekli maruz kaldıkları ve olumsuz psikolojik sonuçlar için risk taşıdıklarını bildirmektedir. Sürekli eğitim ve psiko-sosyal desteklerle bu personelin yaşadığı sorunların çözümlenmesi, niteliğinin arttırılması ve çalıșma koşullarının iyileștirilmesi amacıyla hastanelerde, itfaiye, arama kurtarma merkezlerinde çalışmalarda bulunmak gerekir. Amaç, insanlara yardım için giden bu personeli "yardıma muhtaç" duruma getirmemektir (Raphael vd. 1983). Travmatik olaylara müdahale etmiş ve bundan zarar görmüş olan personele, normal yaşama uyum sağlamasını kolaylaştıracak ekonomik ve psiko-sosyal destekler sağlanmalıdır.

Yardım personeli, afetlere ya da acil durumlara müdahaleden sonra zaman içinde gizli kurbanlar haline gelebilir. Yardım personeline ihtiyaçları doğrultusunda, psikolojik yardımın çeşitli türleri sağlanabilir ancak bunların sistematik ve iyi organize edilmiş olması gerekir. Yöneticiler ve iş örgütleri, mesleki eğitim ve yardımlarla, onları desteklemeli ve yaşamlarını kolaylaştıracak hizmetleri planlamalıdır.

$\mathrm{Bu}$ çalışmada; afetlere müdahale eden yardım personelinin yaşamış olduğu psiko-sosyal sorunların neler olduğunu ve afet öncesi ve sonrası dönemlerde onu psikososyal yönden koruyacak ve güçlendirecek müdahalelerin neler olduğu tartışılmaktadır.

Afetlerin yardım personeli üzerinde yaratmış olduğu bazı psikososyal sorunların neler olduğu ve bu personeli güçlendirme stratejilerinden önce aşağıda; afet ve ruh sağlığı ilişkisi, afetin genel görünümü, afetlerin genel sonuçları ile ilgili kısa bilgiler sunulmaktadır.

\section{Afetler ve Ruh Sağlığı}

"Ruhsal Bozuklukların Tanısal ve İstatistiksel El Kitabı V (DSM-V-TR)" tarafından tanımlandığı gibi; travmatik bir olay - ya da böyle bir olaya tanıklık etme - kişinin kendisi veya bir başkasına yönelik algılanan ya da gerçekleșen yaralanma ya da ölüm tehdidine karşı korku, çaresizlik ya da dehşeti tetikler. Travmatik olaylar genellikle birey tarafından yaşamı tehdit edici, beklenmedik ve sık gerçekleşmeyen olaylar olarak algılanır ve yüksek yoğunluk ile karakterize edilir. Ancak, travmatik olaylar bir toplum içinde tekrarlanabilir ve bu ortamlarda bir tehdidin varlı̆̆ sonuçların türü ve şiddetinin genellikle olayın şekline göre değiştiğini göstermektedir (Institute of Medicine 2019; Y1ldırım 2017; Ișıkhan 2016; Ișıkhan 2021).

Afetlerde görülen ilk tepkiler, travmatik olaylara verilen tepkiler olarak düşünülebilir ve bu belirtiler zaman içinde dağıllır. Bu nedenle, uygun müdahalede bulunmak için, hangi kişilerin uzun vadeli ve ciddi sorunlar yaşayabileceklerini ve etkilenebilecek birey sayısını tahmin etmek önemlidir. Bir afetten sonra uzun vadeli etkilenmenin belirleyicileri aslında diğer travmatik olaylarda gözlemlenenlerin çoğunu içermektedir.

Geleneksel olarak, ruh sağlığı araştırmaları afetleri iki kategoriye ayırmıştır: doğal ve insan kaynaklı (tehlikeli madde dökülmeleri, havacılık felaketleri, terörizm ve hatta savaş eylemleri gibi teknolojik) afetleri kapsamaktadır (Institute of Medicine 2019). Bu kategoriler her zaman karşılıklı olarak birbirinden ayrı olmamakla birlikte, şekilde gösterildiği gibi, afete yönelik bireysel müdahalelerin, olayın türüne bağlı olarak değişebileceğini gösteren bazı kanıtlar vardır (Gist ve Lubin 1989). 


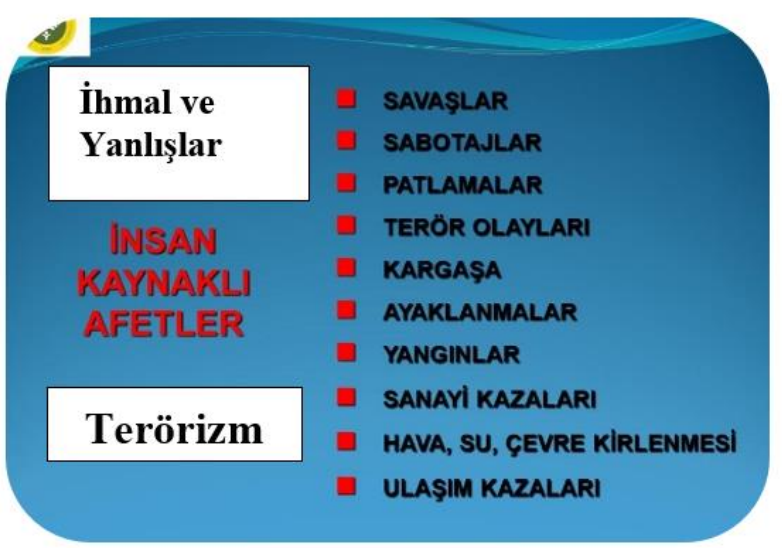

INSAN KAYNAKLI AFETLER

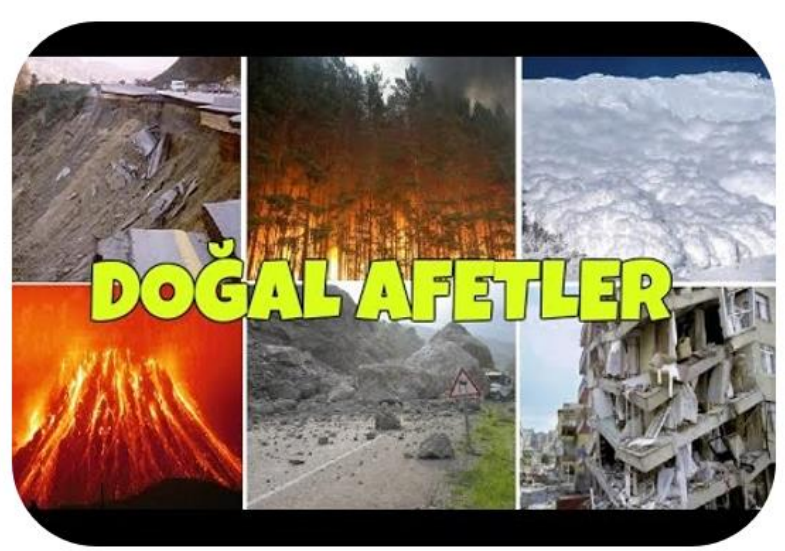

DOĞAL AFETLER

\section{Şekil 1: Afetlerin sınıflandırılması}

Bu alanda yapılan araştırmalar, insan kaynaklı afetlere karşı doğal afetleri tipik olarak incelerken, hangi olayların spesifik bir tepki türüne yol açabileceğine dair bir fikir birliği yoktur. Örneğin; afet literatürünün gözden geçirilmesiyle birlikte, insan kaynaklı afetlerin daha yüksek oranda psikiyatrik hastalıklar ile sonuçlanabileceği görülmüştür. Diğer araştırmalarda insan kaynaklı afetlerin daha kalıcı psikopatolojiye yol açtığı bildirilmiştir (Institute of Medicine 2019).

\section{Afetlerin Genel Sonuçları}

Afet literatürü incelendiğinde afetleri takiben çok çeşitli olumsuz sonuçların ortaya çıktığı görülmüştür. Yapılan incelemeler sonunda çoğu yazarın afetlerin olumsuz psikolojik sonuçlarını rapor ettiğini ortaya koymuştur. Institute of Medicine (2019) tarafından seksen farklı afetin ele alındığı 177 makale incelenmiştir. Bu çalışmada en sık bildirilen negatif sıkıntıları veya sorunları beş kategoriye ayırmışlardır:

- Belirli psikiyatrik hastalıklar (örneğin; TSSB, depresyon)

- Spesifik olmayan sıkıntılar (örneğin; moral bozukluğu, algılanan stres ve negatif etki gibi semptomlar)

- Sağlık sorunları ve endişeleri (örneğin; somatik şikâyetler, uyku bozukluğu, hastalık izni kullanımının artması)

- Yaşamda kronik sorunlar (örneğin; sosyal gerileme, aile çatışması, finansal ve mesleki stres)

- Psiko-sosyal kaynak kaybı (örneğin; sosyal katılım ve algılanan desteğin azalması).

Travmatik bir olayın deneyimi her zaman ciddi psikolojik zorluğa yol açmaz. Hafif anksiyete gibi sıkıntılı tepkiler, hafif uyku güçlüğü gibi davranışsal değişiklikler de tanınabilir. Bir psikiyatrik hastalığın başlangıcına kadar değişen sonuçların görüntüsü vardır. Bu sonuçlar genellikle, müdahale stratejilerine de denk gelen üç şiddet kategorisine sahiptir. Bunlar şu şekilde belirtilebilir:

- İnsanların çoğu, uykusuzluk, üzüntü hissetme, endişelenme ve sigara veya alkol kullanımının artması gibi hafif rahatsızlık tepkileri ve/veya davranış değişiklikleri yaşayabilir. Bu bireyler tedavi olmaksızın iyileşebilirler. Ayrıca eğitim ve toplum çapında destekleyici müdahalelerden yararlanabilirler.

- Daha küçük bir grup, kalıcı uykusuzluk ve endişe gibi daha 1lımlı semptomlara sahip olabilir ve muhtemelen psikolojik ve tıbbi hizmetlerden faydalanacaktır.

- Küçük bir grupta, ne yazık ki TSSB veya majör depresyon gibi psikiyatrik hastalıklar gelişecek ve bu gruba özel tedaviler gerekecektir (Raphael 1986).

$\mathrm{Bu}$ sonuçların her birini deneyimleyen kişi sayısı, olayın ciddiyetine ve maruz kalmanın yakınlığına bağlı olarak göstereceği tepkiler de değişir. Çoğu insan bu travmaları hafif veya seyrek belirtilerle atlatır (Institute of Medicine 2019). Psikiyatrik hastalıklara ve sıkıntı verici tepkilere ek olarak, bir afet yaşanması sağlıkla ilgili davranışlarda ve genel yaşamda önemli değişiklikler yaratabilir. Madde kullanımı, genel olarak afet sonrasında artmakta olduğu düşünülen sağlıkla ilgili bir davranıştır. Herhangi bir travmatik olaydan sonra TSSB'si olan bireylerde sigara ve alkol kullanımı artabilir. Afet çalışmalarının kapsamlı gözden geçirilmesinde, araştırılan nüfusun \%25'inde madde kullanımının arttığ gözlenmiştir (Institute of Medicine 2003; Koçak 2018; Institute of Medicine 2019).

Yardım personelinin yangın, sel, deprem, trafik kazaları, çatışmalar, saldırılar vb. sonrasında mağdurlara yönelik yaptığı müdahalelerin onlarda bıraktığı izler önemlidir. Personelin yaşadığı travmaların, ölümlerin, cesetlerle karşılaşmanın yarattığı duyguların, düşüncelerin, başarı ve başarısızlıkların, çaresizlik, ölüm ve kayıpların sonunda ortaya çıkan tepkilerin ve semptomların tanınması önemlidir. 


\section{Afetlere Müdahale Eden Yardım Personelinin Gösterdiği Tepkiler}

Konuyla ilgili literatür ve yapılan araştırmalar; ne yazık ki birçok yardım personelinin, afet veya kazadan birkaç ay sonra dahi yaşadıkları olayların etkisinden kurtulamadığını göstermektedir (Raphael vd. 1983; Neria vd. 2008). Bu personelin yaşadığı duyguların yoğunlaşmasına etkide bulunan bazı risk faktörleri söz konusudur. Bunlar;

- Afet sonrası tahribatın önemli oluşu (ölü ve yaralının fazlalığı),

- parçalanmış, kopmuş veya toprak altında kalmış vücutlarla karşılaşmak,

- çı̆̆lıkları işitme,

- mağdurların yakınlarının acı ve kederine tanık olma,

- yoğun baskı altında çalışma,

- yardım edememe ve çaresizlik duyguları,

- aşırı yorgunluk, açlık ya da uykusuzluk,

- zehirleyici maddelere maruz kalma,

- ceset kokular1,

- pis kokular, kan, bunları hatırlatan olaylar ve kâbuslardır.

Personelin yaşadığı bu sorunlar yaşamlarını fazlasıyla etkilemektedir. Yardım için koştukları afetler zamanla adeta "kendileri için kişisel bir felakete" dönüşebilmektedir. Yardım personelinin gösterdiği bu tepkilerin anlaşılması müdahale planlarının hazırlanması sürecinde önemli bir yere sahiptir.

Afetlere müdahale eden yardım personelinde ortaya çıkan önemli tepkiler arasında şunlar yer almaktadır:

Psikolojik Tepkiler: Afet çalışmalarına katılmış olan personelin kendisini normalden daha fazla gergin hissettiği, depresif duygular yaşadığı, geçici şok, korku, öfke, suçluluk, utanç, çaresizlik ve umutsuzluk hisleri ya da duygusal donukluk hali yaşadığı, obsesif ve paranoid kişilik özelliği gösterdiği, zihin karışıklığı, konsantrasyon güçlüğü çektiği gözlenmiştir. Afetlerden sonra çoğu personel, içinde bulunulan günü-saati-yeri hatırlayamama, kararsızlık, kuruntu, dikkati bir konuya vermede ya da yoğunlaşmada güçlükler çekme, hafıza kaybı, istenmeyen anıların hatırlanması, kendini suçlama ve uykusuzluk, uyku düzensizliği, kendini bir rüyadaymış gibi hissetme, bazı anıları hatırlayamama hali, aşırı uyarılmışlık hissi, panik ataklar, öfke patlamaları, aşırı huzursuzluk, yoğun duygu yükselmeleri, aşırı kaygı hissetme, aşırı ruhsal çökkünlük hali, umutsuzluk, düşük benlik saygısı, istek ve yaşam amaçlarının kaybı gibi duygular yaşayabilmektedir (Raphael 1986).

Fiziksel Tepkiler: Kalp ve damar hastalıkları (çarpıntı, kalp vurum sayısında düzensizlik ve artış, göğüs ağrıları, hipertansiyon) yanında personelin büyük bir kısmı ülser, migren, bulantı ve diğer mide rahatsızlıkları, yorgunluk, bedensel ağrı ve acılar, ani irkilmeler ve cinsel istekte azalmalar yaşayabilmektedir.

Davranışsal Tepkiler: En önemli davranışsal tepki alkol almadır. Alkol, sorunlardan geçici olarak rahatlama ve kurtulma hissi vermektedir. Personel, sigara ve uyuşturucu kullanma eğiliminin artması, [bunun dikkat ve uyanıklığ1 etkilemesi], iştah azalması veya artması, saldırganlık duygusunun artması ve çalışma motivasyonunun azalması, canlılığını yitirme, ani öfke patlamaları, sürekli kızgınlık davranışları ve yalnızlık duygusu yaşayabilmektedir.

Sosyal ve Ailesel Tepkiler: Afetlerin, personelin iş ve evdeki fonksiyonlarını yerine getirmesindeki etkisi minimal düzeyde olabileceği gibi afetlerden sonra yaşanan deneyimlerin sonucu olarak kendi yaşamı hakkında daha olumlu düşünmesini sağlayabilir. Personelin bu çerçevede yaşadığı bazı sorunlar; sosyal izolasyon, iş, okul, arkadaş ve evlilik yaşamında ya da ana-baba olarak sorunlar yaşama, kişilerarası ilişkilerde kurallara uymama, huzursuzluk, güvensizlik, kendini reddedilmiş ya da terk edilmiş gibi hissetme, insanlarla ilişki kuramama, aşırı yargılayıcı olma, çatışma, her şeyi kontrol altında tutma isteği, iş ortamında işe yaramama duygusu, boşluk içinde olma, sık sık hayal kurmak, performans düşüklüğü, işe gitmeme, işe devamsızlık, yabancılaşma, işinden doyum almama, iş stresinin artması ve motivasyonsuzluk şeklinde olduğu görülmektedir. Yardım personelinin yaralanması, uzuv kaybına uğraması, kaza geçirmesi ve engelli durumuna düşmesi durumunda yaşanılan psikolojik yıkımın ve bu tepkilerin daha da artacağı öngörülebilir.

Doğal ve insan kaynaklı afetlere katılan ve olaydan sonra bu belirtileri gösteren personele, yaşadıkları travmadan hemen sonraki saatlerde ya da günlerde psikososyal destek ekibi tarafından yardım edilmelidir. Bu yardım, psikiyatrist, psikolog, SHU tarafından verilmelidir. Travmaya karşı oluşan ciddi stres tepkilerine kısa sürede ve yeterli bir biçimde müdahale edilmezse, bu belirtiler zamanla TSSB'ye dönüşebilir ve yaşam boyu bireyde düzeltilemeyen rahatsızlıklara neden olabilir (Raphael vd. 1983).

\section{Yardım Personelinde Ortaya Çıkan Semptomlar}

Yardım personelinde ortaya çıkan bu semptomlar aşağıda; TSSB, majör depresyon ve madde kullanım bozukluğu alt başlıklarında kısaca incelenmiştir.

\subsection{Travma Sonrası Stres Bozukluğu (TSSB)}

TSSB “travmatik bir olaya maruz kalma sonucu oluşan ve kâbuslar görme, anımsama, olayı hatırlatıcı uyarıcılardan kaçınma, duygusal tepkilerin hissizleşmesi ve aşırı uyarılmış belirtiler (kısmen dikkatli ve tetikte olma) aracılığıyla olayın tekrar yaşanmasına sebep olan ruhsal bir hastalıktır." TSSB, travmatik bir olayı yaşayanların gösterdiği bir rahatsızlıktır 
ve bu yüzden çoğunlukla genel bir şekilde var olan ve araştırılan afet sonrası psikopatolojidir (Galea vd. 2005; Neria vd. 2008; Norris vd. 2002; Aslan 2018). Literatürde yapılmış çalışmalar TSSB'nin yaygınlığının yaklaşık olarak; doğrudan kurbanlar arasında \%30-40, yardım personeli arasında \%10-20 ve genel nüfusta yüzde 5 ya da 10 arasında olduğu tahmin edilmektedir (Goldman ve Galea 2014).

İngiltere'de kullanılan standart psikiyatrik sınıflamada; TSSB, afetlerin kurbanlarında yaygın olarak görülen bir dizi semptomu tanımlamak için kullanılmaktadır. Bu sendromun 5 özelliği vardır (Alexander 1990). Bunlar:

- Travmatik olayın rüyalarla ve kâbuslarla tekrar tekrar deneyimlenmesi

- Olayın anımsatıcısı karşısında yoğun psikolojik üzüntü

- Belirgin endişe, konsantrasyon sorunları, aşırı irkilme, artmış otonomik aktivite

- Travmanın hatırlatıcılığı olan şeylerden belirgin bir kaçış

- Kişisel ilişkilerde ve zevk veren aktivitelerde azalma.

Açıkçası afetlerin niteliği ve kapsamı değiştiği için genelleme yapmak zordur. Ancak bu kanıtlar, beş yıldan uzun süren etkilerin, yangınla ilgili büyük afetlerde oldukça fazla olduğunu göstermiştir. Daha genel olarak, kronik anksiyete, depresyon, alkol bağımlılığı ve aile içi problemler gibi kronik semptomlar olaydan 2-4 yıl sonra fark edilebilir. Mağdurları uzun süre ölüm ve sakatlanma riskine maruz bırakan afetlerin, ağır ve kronik post-travmatik etkiler bırakması daha muhtemeldir (Gist ve Lubin 1989).

Yeterince şiddetli travmatik mağduriyete karşı hiç kimse bir bağışıklığa sahip değildir. Bir insanın TSSB geliştirme olasılığı, travmatik olayın doğasına bağlı olmakla beraber bireysel farklar bozukluğun alacağı biçimi belirlemede önemli rol oynar. Olay aynı olsa bile, iki insan birbiriyle aynı reaksiyonu vermez. Travmatik sendrom birçok değișmez özelliğine rağmen herkes için aynı değildir. Bu durum yardım personeli için de geçerlidir.

Travmatik olayın etkisi bir dereceye kadar etkilenmiş kişinin esnekliğine de bağlıdır. Her insanın bir "kırılma noktası" olup, bazıları başkalarından daha kolay kırılabilmektedir. Stresli olaylar esnasında sıradan insanlar terör tarafından kolaylıkla felç ya da izole edilirken, yüksek oranda esnekliği olanlar başkalarıyla ahenk içinde her firsatı kullanabilirler.

\subsection{Majör Depresif Bozukluk (MDB)}

MDB, toplumun genelinde görülen en yaygın ruhsal hastalıktır. Üzüntü, bir zamanlar zevk aldığı șeylerden memnun olmama, ilgi kaybı gibi belirtilerle ve uyku, kilo, konsantrasyon zorluğu, sinirlilik gibi diğer belirtilerin bir birleşimi olarak özdeşleşmiştir. Afet araştırmalarında sıralama olarak TSSB'den sonra depresyon ikinci en önemli yaygın araştırılan afet sonrası ruh sağlığı durumudur (Norris vd. 2001). Ancak toplumun genelindeki geniş yükünden dolayı depresyon en yaygın afet sonrası bozukluk olabilir. Araştırmalar, afet sonrasında geniş bir MDB yaygınlığını ortaya koymaktadır. Çünkü tahmin edilen yaygınlık; afet öncesi toplum araştırmalarında MDB yaygınlık belirtilerinin ölçümü, örnekleme tasarımı, afete maruz kalmanın derecesi ve afet sonrası sosyal destek gibi faktörlere dayanarak tahmin edilmektedir (Maguen vd. 2009; Goldmann ve Galea 2014).

\subsection{Madde Kullanım Bozukluğu}

Madde kullanım bozukluğu; ev, iş ya da okul hayatındaki zorluklarda, yasal konularda ve sosyal ilişkilerimizdeki zorluklarda, tehlike durumlarında, başarısız çabalardan vazgeçme sürecinde problemli bir yapı olarak alkol ya da madde kullanımı ile özdeşleşmiştir. Bu durumlar afet sonrası MDB veya TSSB ortaya çıktığından daha az araştırılmıştır. Bazı araştırmalar afet sonrası alkol, ilaç ve sigara kullanımdaki artışı incelemiştir. Bazı kanıtlar afet kurbanlarının madde kullanımının ve kısmen alkol kullanımının bir başa çıkma stratejisi olarak kullanıldığını göstermektedir (Neria vd. 2008). Örneğin; Oklahoma şehrindeki bomba saldırısından sonra hayatta kalanların \%15'nin bu olayla başa çıkmada alkol kullandığı belirlenmiştir (Maguen vd. 2009). Yardım personelinin yaşamış olduğu psikolojik travmalar ne yazık ki başkalarıyla bağların kopması ve güçsüzleşmesine neden olmaktadır. İyileşme süreci, yardım personelinin güçlendirilmesi ve çevresiyle yeni bağların kurulması üzerine odaklanmalıdır.

\section{Güçlendirme Literatürü}

Güç, kişinin bir şeyi başkalarına ihtiyaç duymadan yapması ve başkalarını kontrol edebilmesi, yönetebilmesi anlamına gelmektedir. Güçlendirme kavramı, birey, grup, örgütlerin veya toplumların kendi sistemleri üzerinde kontrol yetisine ve becerisine sahip olmasıdır.

Sosyal hizmet, tarihsel süreçte sürekli dezavantajlı gruplarla çalışmıştır. Sosyal hizmetin temel amacı; birey, grup ve toplumda var olan kaynaklara ulaşılmasını engelleyen koşulları azaltmaya ve ihtiyaçları karşılayarak işlevselliklerini yerine getirmelerine yardımcı olmaktır. Sosyal adalet, eşitlik ve insan hakları sosyal hizmetin en temel kavramlarıdır.

Sosyal hizmetin müracaatçıları; mikro düzeyde-bireyler, aileler ve gruplar, mezzo düzeyde- formel gruplar ve organizasyonlar, makro düzeyde- geniş gruplar ve toplumu içermektedir. SHU, mikro, mezzo ve makro düzeylerde bireylerin sorunlarına çözüm bulmasının yanı sıra birey için değil bireyle birlikte hareket ederek sorunun çözümüne yardımcı olur. Bu düzeyler sorunlara bütüncül bir bakış açısı sunar ve böylece yalnızca tek bir soruna değil, sorundan etkilenen pek çok sistem de çözümün içine katılmış olur (Sheafor ve Horejsi 2003). 
SHU, güçlendirme yaklaşımını kullanırken afetten etkilenen yardım personeline başarının verdiği mutluluğu yaşamasına olanak veren aktiviteler içinde yer almasına yardımcı olur ve geliştirdiği seçeneklerle bu personelin yaşadığı travmanın etkilerini azaltmaya çalışır. Böylece;

- Güçlerinin farkına varan müracaatçı sistemleri (birey, grup ve toplumlar) bunları kullanmaya başlar.

- Kendine güvenmeye başlayan müracaatçı sistemleri güçlerinin farkına varır.

- Başarıyı yaşayan müracaatçı sistemine bir güven duygusu hâkim olur.

Güçlendirme yaklaşımında, yalnızca bireyin güç duygusunu veya becerisini geliştirmek ya da toplumsal değişime yönelik çalışmaya odaklanmak yeterli olmayabilir. Güçlendirmeye dayalı sosyal hizmet uygulaması için bu üç unsurun önemli olduğunu unutmamak gerekir. Bununla birlikte, güçlendirme yaklaşımı sosyal hizmet uygulamasında insanların problem ve sıkıntılarından çok onların, çevrelerinde sahip oldukları kaynaklara ve güçlere odaklanır. Sosyal hizmetin felsefi tutumunda bireylerin içsel ve dişsal güçlerine odaklanılır.

Güçlendirme yaklaşımında, müracaatçının güçleri üzerinden değerlendirmeler yapılmalıdır. Müracaatçıların amaçlarına ulaşmaları için onların sahip olduğu bilgi, yetenek ve kaynakların sistematik olarak kullanılması üzerinde durulur. Güçlendirme yaklaşımında müracaatçılara; iç görü kazandırma, iletişim, sorunun etkisini analiz edebilme, cesaretlendirme, öğretme gibi bazı özel teknikler öğretilir. Geçmişte yaşanan travmaların şu anki yaşamları üzerindeki olumlu ve olumsuz etkilerini anlamalarına yardımcı olunur (Pincus ve Minahan 1973).

SHU'ları zor yaşam problemleri ve çoğunlukla yoğun psiko-sosyal sorunlar yaşayan insanlarla çalışmaktadır. Bazı bireyler sorunları üzerinde ustalıkla durarak bunların üstesinden kolayca gelebilirken bazıları da sahip olamadıkları bazı donanımlar nedeniyle sorunlarıyla nasıl baş edeceklerini bilemezler. Bu kapsamda güçlendirme yaklaşımını kullanarak bireye yardım etmek için; bireyin kendisine saygı ve kendi değeri güçlendirilebilir. Belirlenmiş güçlerini saptayarak birlikte problemlerini çözme yolları tanımlanır.

\section{Yardım Personelini Güçlendirme}

Yaşanılan travma sürecine bağlı olarak iyileşmenin en önemli hedefi yardım personelinin güçlendirilmesidir. Personel, kendi iyileşmesinin hem uzmanı ve hem de hakemi olmalıdır. Çevresindeki bireyler tavsiyede bulunabilir, destek, yardım, sevecenlik ve bakım sunabilir fakat tedavi hizmetini sunamazlar. Güçlendirme ile personelin; gücünü onarma, yalnızlı̆̆ı azaltma, mağdurun seçim yelpazesini genişleterek çaresizliği azaltma ve mağdurun yaklaşımda hâkimiyet dinamiklerine karşı koyması hedeflenir. Yardım personeline yönelik planlanan iyileşmede; güvenliğin tesis edilmesi en önemli basamak iken, hatırlama ve yas ikinci aşamanın temel görevini oluşturur. Son evrede ise normal hayatla yeniden bağ kurmak önemli bir hedef niteliğindedir.

Bir afetten diğerine koşan yardım personeli, işi gereği yardım ettiği insanların ölüm, acı, çaresizlik, üzüntü, başarı ve başarısızlıklara ve ölüm, kayıp ve yas gibi ortak deneyimlerine şahit olabilir. Afetten sonra yaşamış olduğu bu tür sıkıntılar psikolojik sorunlara ve TSSB'ye dönüşebilir. Etkin ya da sağlıklı başa çıkma yöntemlerini kullanamayan yardım personeli profesyonel desteğe ihtiyaç duyabilir ve müracaatçı durumuna gelebilir. Psikososyal destek ekibinden, psikiyatrist, SHU, psikolog, yardım ve danışmanlık hizmetleri alabilir. Bu çerçevede yardım personelinin güçlendirilmesine çalışılmalıdır. Yardım personelinin mağdurlarla kuracağı ilişkinin sağlıklı bir şekilde işleyebilmesi için bazı bilgilere ihtiyaç duymaktadır. Aşağıda kısaca ele alınan bu bilgiler personelin yaşayacağı sorunların yapı ve niteliğini etkileyecektir (Lee ve Henderson 1996):

Probleme Odaklanmak: Doğal olarak yardım isteyen kişiler, problemli, başı dertte, sorunlarını çözmede yetersiz kalan insanlardır. Karşı tarafın gördüğü ve dikkate aldığı noktalar da hep bu olumsuz noktalardır. Kişi hakkında iyi, olumlu ve sağlıklı olan bölümler genelde ve çoğunlukla göz ardı edilir. Senaryo, "bireye yardım edebilmek için sadece hatayı bulmanın yeterli olduğu” üzerine kurulmuştur. Zamanın kısıtlı, işin yoğun olduğu durumlarda müracaatçının, mağdurun veya hastanın olumlu yönleriyle ilgilenmenin lüks olarak görülmesi, işi daha da güçleştirmektedir. Olayın diğer bir yönü de hasta veya mağdurun hizmetini aldıktan sonra ortadan kaybolmasıdır. Kişiler hasta oldukları zaman doktora giderler. Diğer bir deyişle, doktor, hastasıyla sadece sorunlu zamanlarda iletişim kurma olanağına sahiptir. Bütün bunlar insanlar hakkında olumsuz bakış açısını ve tükenmişliği körükleyen faktörlerdir.

Olumlu Geribildirim Eksikliği: Başkaları için bir şeyler yaptığımızda, işimizin takdir edilmesi hoşumuza gider. Çalışmamızın boşa gitmediğini görmek bizi sevindirir. Fakat çoğu zaman, çalışanlar şikâyetleri ve eleştirileri de dinlemek zorunda kalırlar. Bazen de hastalar, mağdurlar ve vatandaşlar teşekkürü gereksiz görür. Çalışanın hizmetinin karşılığı olarak parasını aldığını ve dolayısıyla daha fazla bir şey istemeye hakkı olmadığını düşünürler.

Duygusal Stres Düzeyi: Bazı durumlarda insanlarla ilişki kurmak oldukça zor, üzücü ve sıkıcı olabilir. Ölüm anındaki birisiyle iletişim kurmak ya da hastayı ölümcül hastalığı konusunda bilgilendirmek herkesin duygusal olarak üstesinden gelebileceği kolay bir iş değildir. Yapılan araştırmalar tıp öğrencilerinin duygusal olarak en çok zorlandığı deneyimin hastayı veya ailesini ölümcül hastalık konusunda uyarmak olduğunu ortaya koymuştur. Deprem sonrasında çöken binaların altından çıkarılan cesetleri sahiplerine vermek ve ölüm karşısında yaşanan çaresizlikler personeli aynı ölçüde duygusal yönden zorlayan olaylardır. Hasta ve personelin hatalı olmadığı böyle bir durumda, doktor veya yönetici bu isyan ve kızgınlığı diğer insanlara yansıtabilir. 
Değişim Olasıllğının Zayıfllğı: Kişiler olayları yönlendirme gücünü kendilerinde bulamazlarsa, insanlar hakkında olumsuz duygular geliştireceklerdir. Haklı olduğu halde dinlenme ve tatil hakkını dahi kullanamayan personel için de benzer durumlar söz konusudur. Çaresizlikten kaynaklanan bu durum, çalışanı, öfke ve kızgınlığa sevk eder (Lee ve Henderson 1996). Çaresizlik, yardım personelinin yaşadığı en önemli stresördür.

Karşılaki Insanların Durumu: Sizden bir şeyler isteyen bir birey, sizi ona istediğini vermeye motive edebilir. Bunun yanında karşınızdaki kişinin özellikleri sizin yardımınızın nitelik ve niceliğini etkiler. Kişisel ilişkilerimizde bize neşe veren, bize benzer değer yargılarına sahip insanlarla birlikte olmak isteriz. Oysa iș ilişkilerinde çoğu zaman seçeneğimiz yoktur. Sürekli bir şeyler talep eden, derdini anlatamayan, talimatları uygulamayan, sabırsız, sıkıntıll, sürekli sorun çıkaran insanları "kötü" olarak değerlendireceğimiz şüphesizdir. Böyle bir grupla ilgilenmek zorunda kalan kişi sürekli kendinden ödün vermek zorunda kalacaktır. Bundan da öte tükenmişliğin gelişmesi için ideal bir ortam hazırlayacaktır.

\section{Sonuç ve Öneriler}

Travmatik olayların insanları nasıl etkilediği uzun yıllar boyunca çalışma konusu olmuştur. Çok sayıda araştırma, trafik kazaları ve cinsel saldırı gibi bireysel olaylardan doğal afetler, uçak kazaları ve toplumsal şiddet gibi toplum çapındaki olaylara ve savaş gibi küresel olaylara kadar değişen travmatik olayları incelemiştir.

Terörizm, kolektif korku ve belirsizliği kışkırtır. Bu korku hızla yayılabilir. Olayları doğrudan deneyimleyen kişilerle de sınırlı kalmaz. Etkilenenleri, mağdurları ve hayatta kalanların aile üyeleri ve yayınlanmış görüntülere maruz kalan kişileri içerir. Bazı afetler ani ve beklenmediktir. Bazıları daha yavaş gelişebilir. Bu da bize bir sonraki etkiyi azaltmaya yardımcı olabilecek fiziksel, sosyal ve psikolojik hazırlık zamanı sağlar. Denizdeki afetler, yangınlar ve patlamalar, çok yüksek travma sonrası psikiyatrik hastalık riski taşımaktadır. Psikolojik acı genellikle terörizm olayından kaynaklanan fiziksel yaralanmalardan daha yaygındır. Bu psikolojik sonuçların anlaşılması, bir ulusun terörizm karşııtı psikolojik etkilerini sınırlayacak olan olay öncesi, olay ve olay sonrasında aşamalarında geliştirilecek müdahale stratejileri için kritik öneme sahiptir (Institute of Medicine 2019).

Afet ruh sağlı̆̆ literatüründen elde edilen bulgular, ilk müdahaleyi yapan yardım personelinin, afetlere müdahale ettikten sonra travmatik deneyimlere doğrudan ve sürekli maruz kaldıklarından olumsuz psikolojik sonuçlar için bir risk taşıdıklarını bildirmektedir.

Arama ve kurtarma çalışmalarına katılan bu yardım personeline, ortaya çıkabilecek sorun ve zorlanmalara, görevleri sırasında karşılaşabileceği zorluklara ve bunlarla nasıl mücadele edecekleri konularında eğitimler vererek yardımcı olmamız gerekir. SHU, en temelde sosyal işlevsellik üzerinde durarak; stres ve baskı altında kalan veya travma yaşamış yardım personeline, kişiliğinin güçlü yönlerini görerek sorununu çözerken bunu kullanabilmesine, çevreye uyum yapabilmesine, psikososyal fonksiyonlarını gereği gibi yerine getirebilmesine ve bozulan veya zarar gören ego fonksiyonlarını güçlendirerek sorun çözme yeteneğini artırmasına yardımcı olabilir.

Personelin yaşadığı travma sürecinde ortaya çıkan duygu durumuna etkide bulunabilecek önemli bir faktör ise personelin ailesi ve sosyal çevresinden aldığı sosyal destektir. Sosyal çevresiyle güçlü ilişkileri olan bir kişiye göre psikolojik olarak kendini yetersiz ya da zayıf olarak algılayan kişi daha çok stresten etkilenmektedir. Aileden gelen her türlü sosyal destek, işle ilgili olumsuzlukları, çevreden gelen eleş̧iri ve baskıları azaltarak iyileştirici etki yapmaktadır. Bunlara sahip olamayan personele gereken sosyal destek profesyonel meslek elemanları tarafindan sağlanmalıdır (Tufan 2000). SHU tarafindan oluşturulan grup toplantılarında, personelin kendisini daha iyi tanıması, grup sürecinde bilgi paylaşımında duygularını açıklar, deneyimlerini paylașır, korkular ve başarılar yeniden yaşanır ve korkunç olaylar tüm grup tarafından adeta yeniden yaşanır. Așırı stresli çalışma ortamındaki ekip üyelerinin liderleri, grup çalışmalarının önemini kavramıştır. Bu seansların, potansiyel "iyileştirici" ve "rahatlatıcı" yönü, toplantılara katılanlar tarafından da doğrulanmaktadır.

Yardım personelinin yaşamıș olduğu en önemli olgu tükenmişlik üzerinde ayrıca çalışmak gerekir. Bu personelin yoğun bir tükenmişlik yaşadığını ya da yaşayabileceğini kabul etmemiz gerekir. Tükenmişliği önlemenin ilk aşamašı tükenmişliğin hayatta var olduğunun kabul edilmesidir. Gerçeğin inkâr edilmesi bizi sadece daha fazla tükenmişliğe götürür. Tükenmişliğin nedenlerini tanımlamalı ve problemin üzerine gitmek için doğru bir plan yapmamız gerekir. Yetersiz uyku, sıkıntıların ve olaylarla ilgili olumlu veya olumsuz duyguların paylaşılması, personelin zamanla tükenebileceğini bu yüzden sorumluluklarının paylaşılması konusunda onlara yardımcı olunması ve stres yönetimine yönelik olarak hobilere zaman ayırmanın önemli olduğunun altını çizmemiz gerekir (Işıkhan 2016; Işıkhan 2021).

Yardım personelinin yaşadığı sorunların giderilmesi amacıyla örgütsel düzeyde; personeli eğitmek, işi zenginleştirmek, etkili zaman yönetimini sağlamak, olumlu geri bildirimler vererek takdir edildiklerini göstermemiz gerekir. Ayrıca çalışana yardım programları aracılığıyla; yardım personelinin kendisinin olumlu ve olumsuz yönlerini tanıması, yaşadığı güçlüklerin dile getirilmesi, güçlendirilmesi ve desteklenmesi gerekir. İnsan kaynakları her çalışanı bu program hakkında bilgilendirmek için çabalamalıdır. İşyeri hem tükenmişliğin kaynaklandığı yer olabilir hem de çözüm aranan bir yer olabilir. Bu programların kurumsallaştııılmasıyla gelecekte ortaya çıkabilecek duygusal veya sağlık sorunları giderilmeye çalışılmalıdır. 


\section{Kaynaklar}

Alexander D.A., (1990), Psychological intervention for victims and helpers after disasters, British Journal of General Practice, 40, 345-348.

Aslan H., (2018), SHO 712 Nicel araştırma tasarımları adlı ders kapsamında hazırlanmış ve yayınlanmamış rapor, H.Ü. Sosyal Bilimler Enstitüsü, Ankara.

Burkle F.M. Jr., (1996), Acute-phase mental health consequences of disasters: implications for triage and emergency medical services. Ann. Emerg. Med., 28(2), 119-28.

Galea S., Nandi A., Vlahov, D., (2005), The epidemiology of post-traumatic stress disorder after disasters, Epidemiol. Rev., 27, 7891.

Gist R., Lubin B., (1989), Psychosocial aspects of disaster, John Wiley \& Sons, New York, USA. 357ss.

Goldmann E., Galea, S., (2014), Mental health consequences of disasters, Annu. Rev. Public Health, 35, 169-83.

Institute of Medicine, (2003), Preparing for the Psychological Consequences of Terrorism: A Public Health Strategy, Institute of Medicine; Board on Neuroscience and Behavioral Health; Committee on Responding to the Psychological Consequences of Terrorism, https://www.nap.edu/initiative/committee-on-responding-to-the-psychological-consequences-of-terrorism, [Erişim Tarihi: 12 Aralık 2020].

Institute of Medicine, (2019), Understanding the psychological consequences of traumatic events, disasters, and terrorism, Institute of Medicine; Board on Neuroscience and Behavioral Health; Committee on Responding to the Psychological Consequences of Terrorism, https://www.ncbi.nlm.nih.gov/books/ NBK221638/ [Erişim Tarihi: 12 Aralık 2020].

Işıkhan V., (2016), Stres yönetimi: tükenmişlikten mutluluğa, Nika Yayınevi, Ankara, 420ss.

Işıkhan V., (2021), Yardım personelini güçlendirme, Nika Yayınevi, Ankara, 352ss.

Koçak Y.E., (2018), SHO 712 Nicel araştırma tasarımları adlı ders kapsamında hazırlanmış ve yayınlanmamış rapor, H.Ü. Sosyal Bilimler Enstitüsü, Ankara.

Lee V., Henderson, M. (1996), Occupational stress and organizational commitment in nurse administrators, Journal of Nursing Administration, 26(5), 21-28.

Maguen S., Neria Y., Conoscenti L.M., Litz B.T., (2009), Depression and prolonged grief in the wake of disasters, Mental health and disasters'in İçinde (Neria Y., Galca S., Norris FH., Ed.), Cambrigde University Press, New York, USA, ss. 116-130.

McFarlane A.C., Williams, R., (2012), Mental health services required after disasters: learning from the lasting effects of disasters, Depress Res Treat., 2012:970194, doi: 10.1155/2012/970194.

Neria Y., Nandi A., Galea S., (2008), Post-traumatic stress disorder following disasters: a systematic review, Psychol Med., 38, 46780.

Norris F., Friedman M.J., Watson P.J., (2002), 60,000 disaster victims speak: Part II. Summary and implications of the disaster mental health research, Psychiatry, 65, 240-60.

Norris F., Perilla, J., Ibanez G., Murphy A. (2001), Sex differences in symptoms of posttraumatic stress: Does culture play a role? Journal of Traumatic Stress, 14, 7-28.

Pincus A., Minahan A., (1973), Social work practice: model and method, F.E. Peacock Publishers, Itasca, IL, USA, 355ss.

Raphael B. (1986), When Disaster Strikes: How Individuals and Communities Cope With Catastrophe, Basic Books, NewYork, USA, 342 ss.

Raphael B.S., Bradburg L., Lambert F., (1983), Who helps the helpers? The effects of a disaster on the rescue workers, Omega, 14(1), 9-20.

Sheafor B.W, Horejsi C.R., (2003), Techniques and guidelines for social work practice (6th Edition), Allyn ve Bacon, Boston, MA, 645ss.

Tufan B., (2000), Afet hizmetleri ve sosyal hizmet uzmanları, Sağlık ve Toplum, 10(Özel Sayı), 39-44.

Yıldırım A., (2017), SHO 712 Nicel araştırma tasarımları adlı ders kapsamında hazırlanmış ve yayınlanmamış rapor, H.Ü. Sosyal Bilimler Enstitüsü, Ankara. 